\title{
CONDITIONS FOR DEVELOPMENT \\ OF ENTREPRENEURSHIP IN REGIONS OF VISEGRAD GROUP COUNTRIES
}

\section{Małgorzata Jabłońskaa (iD, Joanna Fila ${ }^{a}$}

\begin{abstract}
The aim of this paper is to analyse and evaluate the directions of changes in the development of entrepreneurship in the regions of the Visegrad Group countries, i.e., the Czech Republic, Poland, Slovakia and Hungary, in the period 2004-2018. We carried out research using an entrepreneurship model based on the Global Entrepreneurship Monitor (GEM) methodology. The literature analysis made it possible to formulate the main research hypothesis, which states that the factors of entrepreneurship development in this period had a different impact on the establishment of enterprises at the level of regions in the Visegrad Group countries. Assigning individual regions of these countries to entrepreneurship classes in the investigated years showed significant differences, which means that the NUTS 2 regions of the Visegrad Group countries differ significantly in terms of entrepreneurship development conditions.
\end{abstract}

Keywords: Entrepreneurship, SME, GEM, regions, finance, economy

JEL Classification: G30, G10, O16, K40

\section{Introduction}

Entrepreneurship is of fundamental importance for the dynamics of economic development, and it strongly influences the economic growth of countries and regions. The decision to start one's own business is determined by many factors. Social, cultural, political and economic conditions can have a positive or negative impact on the development of entrepreneurship in the economy. The area of entrepreneurship concerns interdisciplinary theories and approaches, which is why researchers analyse the phenomenon in different ways.

The aim of this paper is to analyse and evaluate the directions of changes in entrepreneurship development in the regions of the Visegrad Group countries, i.e., the Czech Republic, Poland, Slovakia and Hungary, in the period 2004-2018. The surveys referred to in the paper will be carried out using an entrepreneurship model based on the Global

a Department of Finance and Accounting of SMEs, University of Lodz, Poland

Emails: malgorzata.jablonska@uni.lodz.pl,joanna.fila@uni.lodz.pl 
Entrepreneurship Monitor (GEM) methodology. The GEM is an international research project focused on entrepreneurship and dissemination of knowledge about it, as well as supporting the creation of enterprises around the world.

The selection of countries in which the investigated regions (classified according to NUTS $2^{1}$ ) are located was determined by several factors. All these countries are located in Central and Eastern Europe, and all of them transformed from a centrally planned economy to a market economy in the early 1990s. They all joined the European Union on 1 May 2004, thus becoming beneficiaries of assistance from the Structural Funds or the EU Cohesion Fund, which encouraged the development of entrepreneurship at many levels. It can therefore be concluded that all these countries were in a similar situation as regards the conditions for the construction and development of the small and medium-sized enterprises (SME) sector $^{2}$. Presenting data at the regional level, which are used in the paper, is also justified by the fact that the regions are unique and have different economic and social conditions. They are also a separate area of support from the perspective of the EU regional policy.

The main research hypothesis is as follows. Entrepreneurship development factors in the period 2004-2018 had a different impact on the creation of enterprises at the level of regions in the Visegrad Group countries.

The paper is divided as follows. The first section presents the topic and the research problem as well as a review of previous research. Desk research was performed and was based on literature studies, thanks to which it was possible to formulate the main research hypothesis. The next section discusses the research methodology, and then the results of the analysis are presented. The paper ends with conclusions from the research, restrictions and future trends in the area of research on regional entrepreneurship in the Visegrad Group countries.

\section{Literature Review}

\subsection{Entrepreneurship in Visegrad Group countries}

The SME sector is an important element of any market economy. The phenomenon of entrepreneurship is also subject to analysis and assessment at the local, national, and international levels. Creating a favourable climate for the development of entrepreneurship

1 NUTS (Nomenclature des Unités territoriales statistiques in French, Nomenclature of territorial units for statistics in English) is a geographical nomenclature subdividing the economic territory of the European Union into regions at three different levels. NUTS 2 relates to the "regional" level of the Member States used in most cases for international comparison.

2 The factor differentiating Slovakia from Poland, the Czech Republic and Hungary is the fact that it has been a member of the eurozone since 2009, which has stabilized the Slovak economy. 
is a process that combines many threads and impact areas. One of the global rankings is the "Doing Business" report published by the World Bank, which analyses and assesses the conditions for starting a business in nearly 200 countries around the world. In the 2019 report, Poland was in 33rd place, the Czech Republic 35th, Slovakia 42nd and Hungary 53rd. The overall position of these countries in the ranking is the result of various factors related to running a business, such as the number of days needed to set up a firm, capital requirements, the complexity of the tax system and the amount of tax burden, the level of bureaucratization or the availability of loans. The above factors are just a selection from the entire range. Many other aspects influence entrepreneurial motivations, activities, attitudes and perceptions.

The entrepreneurial attitudes and perceptions in the Visegrad Group countries are very diverse. In terms of perceiving opportunities, the Visegrad Group countries are below the EU average, while their entrepreneurial intentions are above the EU average. The entrepreneurial activities of new enterprises, or those which are emerging and in the early stages, are above the EU average in almost all the Visegrad Group countries, with the exception of the Czech Republic. However, only the improvement-driven entrepreneurial motivations in the Czech Republic are above the EU average. Entrepreneurial aspirations in the Visegrad Group countries, measured by expectations for job growth, appear to be higher than the EU average. In turn, education in the field of entrepreneurship at primary and secondary levels of education is rated unfavourably in most economies. In contrast, physical infrastructure is rated positively, and it is above the EU average (Cerić, 2015).

In the case of Slovakia, the entrepreneurs are conservative when it comes to accepting partners and expanding the scope of their activities thanks to external capital, while at the same time, there are problems obtaining bank loans (Š́ubertová, 2009). The entrepreneurial environment in Slovakia presents some cognitive and normative strengths, e.g., confidence, the presence of networks and uncertainty avoidance, all of which have a positive effect on entrepreneurship in Slovakia. On the other hand, government policy is a weakness, as it should focus on supporting entrepreneurship (Holienka, 2015).

The detailed analysis of Hungarian regions has shown that they are particularly weak in terms of entrepreneurial attitudes. On the one hand, the results show that Hungarian firms present reduced levels of innovation activity. The analysis, which is based on the individual characteristics of Hungarian entrepreneurs, shows that they lack startup skills and usually also have a negative attitude towards potential economic and business opportunities (Szerb et al., 2013).

In Poland, the entrepreneurial intentions are below the EU average as is the fear of failure. On the other hand, the self-assessment of entrepreneurial capabilities is much better and business opportunities are perceived especially optimistically (PARP, 2018). 
The decline in entrepreneurial intentions of Poles recorded last year may be a delayed effect of the situation on the labour market, which has been improving for several years. The stability of the labour market means that, similarly to highly developed economies, fewer people think about running their own business. Perhaps this is a consequence of the low unemployment retain effect. It means that in periods of low unemployment, the interest in starting one's own business decreases due to the high availability of hired job offers (Sorgner and Fritsch, 2018).

\subsection{Entrepreneurship according to Global Entrepreneurship Monitor}

The GEM is a networked consortium of national country teams primarily associated with top academic institutions. It carries out survey-based research on entrepreneurship and entrepreneurship ecosystems around the world and is the only global research source that collects data directly from entrepreneurs. GEM started in 1999 as a joint research project of Babson College (USA) and London Business School (UK). The first annual study covered 10 countries and since then some 115 countries have participated in GEM research. The GEM can be described as a consortium of "national teams". Each team is led by a local university or academic institution and is the official national representative of the project. All national teams are also national sponsors, since they contribute resources to the GEM in kind and/or in cash. ${ }^{3}$ National teams are responsible for raising funding for GEM activities in their respective countries, for example from academic institutions, local and national governments, foundations, aid agencies and banks (www. gemconsortium.org/about/gem).

The total early-stage entrepreneurial activity rate (TEA) is the most important measure used by the GEM to determine the percentage of people aged 18-64 in the economy who are new entrepreneurs or owners-managers of new business ventures (Anton and Onofrei, 2016; Global Entrepreneurship Monitor, 2011). The periodic GEM reports present a multiperspective analysis of entrepreneurship development conditions. The main parameters analysed and assessed by the GEM include:

- financing,

- government policy,

- tax systems,

3 The legal entity of the GEM is a company limited by guarantee and without share capital that is registered as the "Global Entrepreneurship Research Association" (GERA) in England and Wales. The Association of GEM National Teams (AGNT) is a non-profit association that exists primarily for the representation of GEM National Teams within GERA. 
- education systems,

- research and development (R\&D) expenditures,

- commercial and professional infrastructure,

- internal market dynamics and openness (GDP per capita in euros),

- physical and service infrastructure,

- cultural and social norms,

- total activity in the early stage of entrepreneurship.

These parameters are among the most representative and most frequently mentioned, not only in the GEM methodology. They are also emphasized in the literature on the subject, which is based on data from GEM reports, and which will be presented below.

Capital, i.e., financing in general, is a key condition for starting and running a business. What is important here is the general availability of financing sources, including capital funds, debt amortization for new enterprises and for those in the growth phase, as well as subsidies (Roper and Scott, 2009; Korosteleva and Mickiewicz, 2011; Anton and Onofrei, 2016). The supply of capital and its costs have been the subject of many analyses, both in theory and in economic practice (Storey, 1994; Beck et al., 2005; OECD, 2006). A common problem of newly emerging economic entities is obtaining financing tailored to their needs. New growth-oriented enterprises require the involvement of advanced financial institutions and a developed financial system (Korosteleva and Mickiewicz, 2011).

The level of entrepreneurial activity is significantly related to economic freedom. Both the extent of government policy interference and the nature of monetary policy can strongly affect entrepreneurship in a given country or region (Bjørnskov and Foss, 2006). The nature of government policy and the degree to which it is neutral in terms of the size of enterprises (e.g., in the area of taxes, regulations and their application) may also be relevant. From this point of view, it is also important whether the pursued policy encourages or discourages economic activity and development (Poschke, 2013; Levie et al., 2014; Anton and Onofrei, 2016). Government policy shapes the tax system, and its regulations have an impact on the functioning of enterprises (Díaz-Casero et al., 2012).

Government policy is also expressed by shaping of the education system. Many studies emphasize a causal relationship between education and economic growth (Oancea et al., 2017) and the role of quality, relevance and scope of the educational offer (Fossen and Büttner, 2013). This may particularly apply to the unemployed who see their own business opportunity as a chance to be employed, generate income and improve their living conditions (Dvouletý, 2017). The higher education sector should focus on current general effects and recognize problem areas (e.g., differences in the level of entrepreneurship 
of women and men, or the functioning of family businesses) and develop initiatives to solve the problems with properly selected instruments (Holienka et al., 2017).

The area of $R \& D$ is currently an important point of interest for any economy that wants to be competitive in relation to other economies. R\&D is a consequence of both the commitment of authorities at the national or regional levels and the independent initiatives of enterprises that see innovation as their chance to win a market. It is therefore important to analyse the extent to which R\&D leads to new business opportunities and the level of access to R\&D by small, new or developing enterprises (Bampoky et al., 2016).

A well-developed business environment and operating in conditions of free competition are also important for the development of entrepreneurship. Therefore, the analysis should cover the impact of organizations and institutions as well as the offered commercial, accounting, and legal services that enable the promotion of small, new or developing enterprises (Curran et al., 2016). Access to physical resources (communication, transport, media, raw materials and natural resources) at prices that are not discriminatory to SMEs or new enterprises, protection of property rights, availability of accounting services, and support through technology parks and business incubators are also important (Holienka et al., 2016).

The last two problems raised by the GEM are the general climate for the development of entrepreneurship and activity in the early stage of entrepreneurship. The degree to which social and cultural norms encourage (or do not discourage) individual initiatives that lead to new ways of doing business, and thus to a greater distribution of wealth and income, should be assessed (Autio et al., 2013; Stuetzer et al., 2014; Turro et al., 2014). Business activity has expectations and motivations in the early stage. Ventures are not started by chance and have specific reasons. Expectations for new ventures are usually overoptimistic in the early start-up stage, being formed under substantial uncertainty (Lukeš and Zouhar, 2016).

The brief review of selected studies presented above indicates conditions for entrepreneurship development. In the following section, we will present research hypotheses and discuss the methodology used to model the measuring of entrepreneurship at the regional level by utilizing the variables discussed above.

\section{Research Hypotheses}

We conducted an analysis and assessment of the phenomenon of entrepreneurship in the Visegrad Group countries. The research was based on data collected at the NUTS 2 level, and it aims to fill a gap that exists in regional entrepreneurship research. The main purpose of the analysis was to calculate the entrepreneurship indicator in selected regions based on 12 variables, which, in our opinion, can influence the development 
of the investigated phenomenon directly and indirectly. A comparative analysis was conducted for 2004 and 2018 to indicate the directions of changes that were taking place in the regions in terms of entrepreneurship development. The results also show similarities and differences between the regions in terms of the created entrepreneurship policy. Based on the literature analysis, we formulated the main research hypothesis, which states that the entrepreneurship development factors in the period 2004-2018 had a different impact on the establishment of enterprises in the regions of the Visegrad Group countries. Two detailed hypotheses were also formulated:

H1: The development of entrepreneurship in the V4 regions is a multidimensional phenomenon that can be analysed within several basic thematic areas: finance, government policy, education system, R\&D expenditures, trade infrastructure, internal market openness and physical infrastructure.

H2: Regional conditions influence the decision to start one's own business by affecting individual characteristics of entrepreneurs and their motivations and by generating regional barriers to entrepreneurship.

\section{Material and Methods}

The empirical research aimed at measuring the regional level of entrepreneurship using a pseudo-single-feature entrepreneurship indicator calculated using the correlation weighting method. The calculations took into account 12 factors that represent the areas indicated in the Global Entrepreneurship Monitor. These areas were discussed in Section 2: financing, government policy, education system, $R \& D$ expenditures, commercial and professional infrastructure, internal market openness and physical infrastructure. When conducting research on the impact of various groups of factors on entrepreneurship, it should be borne in mind that their set will never be finite. We used 12 factors that were available in regional databases at the time of writing and comparable. The features selected for testing made it difficult to limit the set of diagnostic variables, as they had to be available at the level of each country's individual statistical divisions. The choice of these 12 factors was inspired by the GEM research.

In this work, we did not use the cluster analysis widely described in the literature, which would also have been an excellent research method. The indicators determined by the correlation weighting method enable the determination of weights of pseudosingle-feature variables based on the features of the statistical distribution, thus minimizing the subjectivity of the final grades. The undoubted advantage of the correlation weighting method is the researcher's lack of subjectivity in the process of assigning importance to particular variables and the greater degree of describing the phenomenon of potential 
investment attractiveness than in the case of abandoning the weighting process. Therefore, we decided to use the research method described.

The essence of the correlation weighting method lies in the use of Pearson's linear correlation coefficients between pseudo-single-feature variables and the final index, as weights enabling the construction of a synthetic index, used to evaluate territorial units. In this paper, we used quantitative variables from a population with a distribution close to normal not containing outliers that would distort the result.

Table 1: Variables used to construct the entrepreneurship indicator

\begin{tabular}{|c|c|c|}
\hline Variable & $\begin{array}{l}\text { Stimulant (S) / } \\
\text { Destimulant (D) }\end{array}$ & $\begin{array}{l}\text { Areas included } \\
\text { in GEM }\end{array}$ \\
\hline $\begin{array}{l}\text { Net disposable household income per inhabitant } \\
\text { in EUR }\end{array}$ & $\mathrm{S}$ & Funding \\
\hline Unemployment rate of working-age population (\%) & $\mathrm{S}$ & Government policy \\
\hline $\begin{array}{l}\text { Employment rate of people not in education aged } \\
15-34(\%)\end{array}$ & $\mathrm{S}$ & Education system \\
\hline $\begin{array}{l}\text { Share of people aged } 18-24 \text { not working } \\
\text { or in education anywhere }(\%)\end{array}$ & $\mathrm{D}$ & Education system \\
\hline $\begin{array}{l}\text { Share of people aged } 25-64 \text { who graduated from } \\
\text { junior high school, high school or a higher education } \\
\text { institution (\%) }\end{array}$ & $\mathrm{S}$ & Education system \\
\hline Employment in R\&D per enterprise & $\mathrm{S}$ & $\mathrm{R} \& \mathrm{D}$ \\
\hline $\begin{array}{l}\text { R\&D expenditures in enterprise sector per } \\
\text { enterprise (EUR) }\end{array}$ & $\mathrm{S}$ & $R \& D$ \\
\hline Share of people who never used the Internet (\%) & D & $\begin{array}{l}\text { Commercial and } \\
\text { professional } \\
\text { infrastructure }\end{array}$ \\
\hline Real growth rate of regional gross value added (\%) & $\mathrm{S}$ & $\begin{array}{l}\text { Internal market } \\
\text { openness }\end{array}$ \\
\hline GDP per capita (EUR) & $\mathrm{S}$ & $\begin{array}{l}\text { Internal market } \\
\text { openness }\end{array}$ \\
\hline Kilometres of motorways per 100 sq km & $\mathrm{S}$ & $\begin{array}{l}\text { Physical } \\
\text { infrastructure }\end{array}$ \\
\hline Entrepreneurship rate & $\mathrm{S}$ & $\begin{array}{l}\text { Total activity } \\
\text { at the early stage } \\
\text { of entrepreneurship }\end{array}$ \\
\hline
\end{tabular}

Source: Own elaboration. 
Table 1 presents the names of all the variables included in the research and the nature of their impact on the entrepreneurship indicator. It was assumed that the variables appearing in the research as stimulants have a positive impact on the level of entrepreneurship, while destimulants have a negative impact on the development of the phenomenon.

The variables presented above were standardized to be comparable. The following formulas were used (Godlewska-Majkowska, 2008):

- for destimulants: $\frac{X_{\text {maks }}-X_{i}}{X_{\text {maks }}-X_{\text {min }}} \times 100 \%$

- for stimulants: $\frac{X_{i}-X_{\text {min }}}{X_{\text {maks }}-X_{\text {min }}} \times 100 \%$

Thanks to this procedure, all the variables were reduced to values ranging from 0 to 1 . In the case of positive variables, the value of 1 was attributed to the region with the highest indicator among all the analysed regions. Conversely, the negative variables equalled 1 for regions that had the lowest indicator of the negative phenomenon. The results obtained in this way were then used to calculate the correlation coefficients between the initial entrepreneurship indicator and the indicators calculated for each factor taken into account in the analysis. Following the correlation weighting method, the correlation coefficients were then used as weights for the weighted average, and the mean was recalculated (in the first iteration, the arithmetic average was used; in the subsequent ones, the weighted average was used). These calculations were repeated until the correlation coefficients stabilized (Zarębski, 2012). The results obtained after the second iteration (using a weighted average) showed the final values of the entrepreneurship indicator for the NUTS 2 regions of the Visegrad Group. The indicators calculated using this method, both for 2004 and 2018, will be compared and analysed in subsequent parts of the paper.

All the regions were grouped into six entrepreneurship classes. The class ranges were calculated based on the arithmetic mean and standard deviation of the entrepreneurship indicators. Based on these statistics, six entrepreneurship classes were determined (from the most entrepreneurial class $\mathrm{A}$ to class $\mathrm{F}$, which includes the least entrepreneurial regions). These classes are left-closed intervals with lower limits:

- class A: arithmetic average + standard deviation,

- class B: arithmetic average $+0.5 \times$ standard deviation,

- class C: arithmetic average,

- class D: arithmetic average $-0.5 \times$ standard deviation,

- class E: arithmetic average - standard deviation,

- class F: 0 (Godlewska-Majkowska, 2008, p. 38). 


\section{Empirical Perspective and Discussion}

The analysis of the level of entrepreneurship in the period 2004-2018 makes it possible to notice the directions of changes taking place in the entrepreneurial climate in the Visegrad Group. These countries consist of economies that represent a similar level of socio-economic development and which are struggling with similar structural problems (the Visegrad countries joined the European Union at the same time, which also makes them comparable). Calculating the pseudo-single-feature entrepreneurship indicator based on 12 comparable variables allowed classification of individual regions into entrepreneurship classes (see Table A1 in the Appendix).

Based on the calculations, it should be pointed out that in 2004 , i.e., when all the analysed countries joined the European Union, the most entrepreneurial regions were found in the Czech Republic (Prague, Central Bohemia, Southwest and Southeast) Slovakia (Bratislava Region), and Hungary (Budapest and Western Transdanubia). The most important factors for achieving the high value of the entrepreneurship indicator in the Czech Republic were:

- $\quad$ financing - the average value of this parameter in the Visegrad countries was 0.32. All the Czech regions included in the analysis recorded high values of this indicator (the highest in Prague: 0.96);

- education system - the average value of this parameter in the Visegrad countries was 0.51. The Czech regions assigned to class A recorded values close to 1;

- market openness - the average value of this parameter in the Visegrad countries was 0.38. The highest value was recorded in the Prague region (0.63);

- entrepreneurial activity - the average value of this parameter in the Visegrad countries was 0.52. In the analysed regions of the Czech Republic, this parameter ranged from 0.53 to 0.97 .

The areas that had a significant impact on the value of the entrepreneurship indicator in the Bratislava Region of Slovakia, which in consequence allowed the region to be categorized as class A, were:

- financing - the parameter value was practically double the average values recorded in the other analysed NUTS 2 regions ( 0.74 compared to the average in the Visegrad countries of 0.32);

- education system - the value of this parameter in the region was 0.81 , compared to the Visegrad Group average of 0.51 ;

- physical infrastructure - the value of this parameter in the region was 0.47 , compared to the Visegrad Group average of 0.29 . 
Two regions qualified for class A in Hungary. The entrepreneurship indicator was most affected by:

- financing - the Hungarian regions reached 0.51 and 1.0 in this area.

The regions which were least entrepreneurial in 2004 were found in Poland (WarmińskoMazurskie and Świętokrzyskie) and Slovakia (Central Slovakia and Eastern Slovakia). The areas that had a key impact on classifying the regions as group $\mathrm{F}$ were:

- financing - in Poland, this parameter was at an extremely low level of 0.06 and 0.03, and in Slovakia, it was 0.26 and 0.22; meanwhile, the average in the Visegrad Group was 0.32 , and the maximum value was 1 (Budapest);

- physical infrastructure - the value of this parameter in the Polish regions was 0.00 while the Visegrad Group average was 0.29. In the regions of Slovakia, the values fluctuated around the average;

- entrepreneurial activity - this parameter reached values close to zero in the Slovak regions, while in the Polish regions it equalled 0.61 and 0.59; the Visegrad Group average was 0.52 .

Government programmes and policies can support or discourage the creation of new firms and influence their growth. When analysing the calculations, it is worth noting that in the regions that achieved the lowest values of the entrepreneurship indicator, the values of the parameter related to government policy are high - often exceeding the average (e.g., 0.87 for Warmińsko-Mazurskie or 0.93 for Eastern Slovakia, with the group average equalling 0.45). However, in the regions that were characterized by the highest level of the entrepreneurship indicator, the values of this parameter were at a very low level, e.g., 0.00 for Prague and 0.11 for Budapest.

The calculation of the entrepreneurship indicator using the proposed correlation weighting method made it possible to select groups of regions with a similar value of the analysed parameter. Figure 1 shows how the "enterprise groups" developed in NUTS 2 regions in 2004.

Figure 1 shows how many regions in the studied countries were in each entrepreneurship class in 2004. The largest group was class D (11 regions), most of which were in Poland (6), followed by group E, which consisted only of Polish regions (7). Therefore, it can be pointed out that at the time of accession to the European Union, the conditions for the development of entrepreneurship in Polish regions were significantly different and worse than in the other Visegrad Group countries. 
Figure 1: Distribution of entrepreneurship classes in NUTS 2 regions of Visegrad Group based on calculated pseudo-single-feature entrepreneurship indicator in 2004

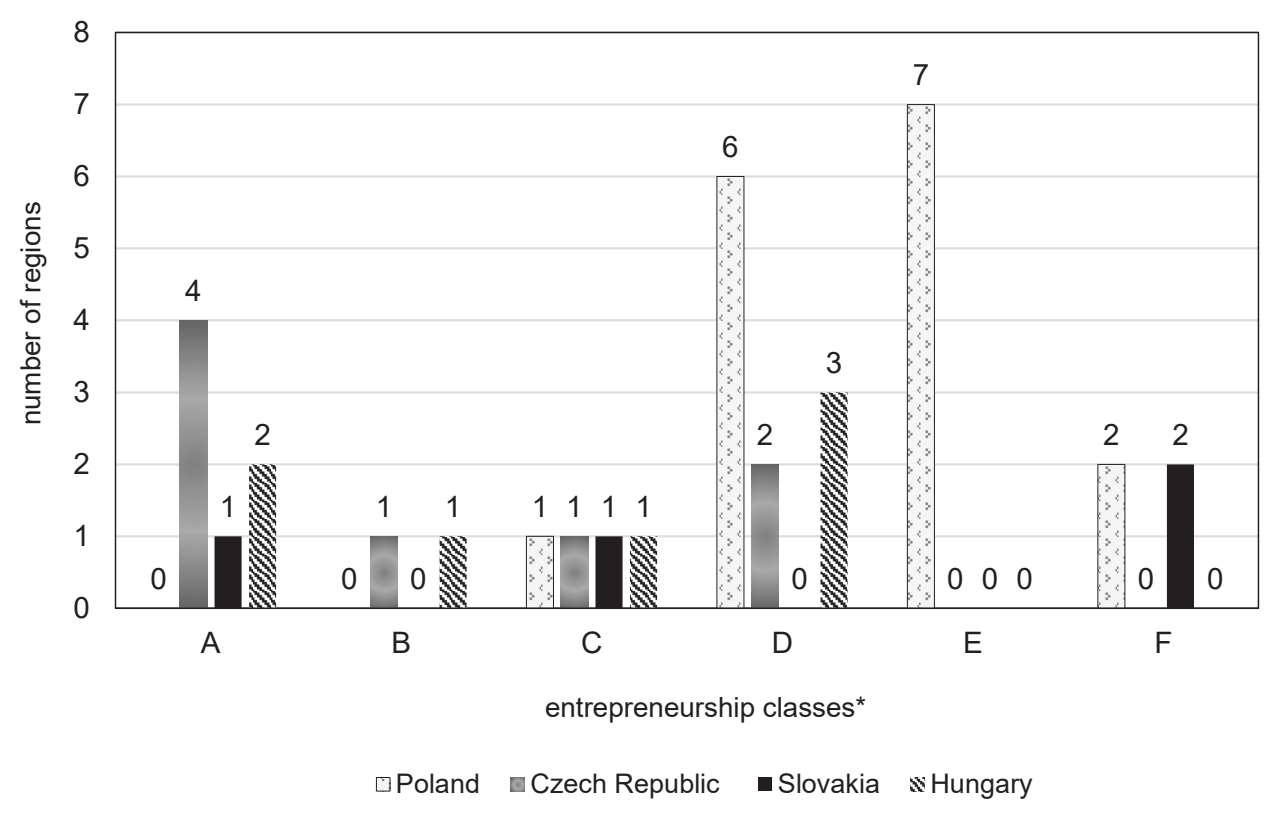

Note: * class A: arithmetic average + standard deviation; class B: arithmetic average $+0.5 \times$ standard deviation; class C: arithmetic average; class D: arithmetic average $-0.5 \times$ standard deviation; class E: arithmetic average - standard deviation; class F: 0 .

Source: Own calculations.

The analogous calculations for 2018 showed that the most entrepreneurial regions included five Czech regions (Prague, Central Bohemia, Southwest, Southeast and Central Moravia - which moved up from class C), one Slovak (Bratislava Region) and one Hungarian (Budapest). The areas that were most important for the high value of the entrepreneurship indicator in these regions were (see Table A2 in the Appendix for details):

- financing - the average level of this indicator in the Visegrad Group countries was 0.23. The Czech regions recorded values ranging from 0.30 to 0.77 , for the Slovak region it was 1.00 , while for the Hungarian one it was 0.15 ;

- the education system - the average level of the indicator in the Visegrad Group countries in 2018 was 0.55 . All the regions included in class A had above-average values; 
- commercial and professional infrastructure - the average level of the indicator in the Visegrad Group countries in 2018 was 0.46 . The class A regions recorded above-average values.

The group of the least entrepreneurial regions in 2018 included four Polish regions (Warmińsko-Mazurskie, Świętokrzyskie, Lubelskie, and Podkarpackie) and one Slovak region (Eastern Slovakia).

Figure 2: Distribution of enterprise classes in NUTS 2 regions of Visegrad Group, based on calculated pseudo-single-feature entrepreneurship indicator in 2018



Note: * class A: arithmetic average + standard deviation; class B: arithmetic average $+0.5 \times$ standard deviation; class C: arithmetic average; class D: arithmetic average $-0.5 \times$ standard deviation; class E: arithmetic average - standard deviation; class F: 0.

Source: Own calculations.

Figure 2 shows how many regions in the studied countries were in each entrepreneurship class in 2018. The comparative study conducted for 2018 showed that some change had occurred in the NUTS 2 regions of the Visegrad Group countries in the context of conditions for the development of entrepreneurship. The Czech regions are still the most entrepreneurial (5 out of 8 regions were in class A in 2018). One Hungarian and one Slovak region moved up to group B. There were 3 Polish regions in group C (Dolnośląskie, Śląskie and Małopolskie - all of which had moved up from group D). 


\section{Conclusion}

We conclude that the development of entrepreneurship is influenced by many variables, which impact on the phenomenon with different intensity and in different directions. Based on twelve factors, the GEM methodology creates a broad field for the analysis of what mostly affects entrepreneurship. Values of the pseudo-single-feature entrepreneurship indicator show that in regions representing the highest entrepreneurship potential, the most important factors are financial conditions and the education system.

Entrepreneurship in the regions of Visegrad countries had improved by 2018 in comparison to 2004. Regions with the highest entrepreneurship potential are mainly located in the Czech Republic. The factors that have the greatest impact on the high values of the parameter in this country are financing and the education system (in both 2004 and 2018), as well as market openness and entrepreneurial activity (in 2004) and commercial and professional infrastructure (in 2018).

The division of individual regions of the Visegrad Group countries into entrepreneurship classes in the analysed years revealed significant differences. The classes bringing together the biggest number of regions were D (11 regions) in 2004 and E ( 7 regions) in 2018, both dominated by Polish voivodeships. Analogous research conducted for 2018 showed that significant changes had taken place in the development of entrepreneurship in the regions of the Visegrad Group countries. Three Polish voivodeships (Dolnośląskie, Śląskie and Małopolskie) had moved up to class $\mathrm{C}$, and three additional regions (apart from the Czech regions, there were also Slovak and Hungarian ones) had joined class A.

Other factors indicated by the GEM as those that could influence entrepreneurship development, such as the tax system, R\&D expenditures or cultural and social norms, are not relevant according to our research. More in-depth analyses might explain the reasons for this and suggest what should be done to make them meaningful. 


\section{Appendix}

Table A1: Average values of variables for the entrepreneurship indicator in the GEM areas in 2004, and the classification of regions

\begin{tabular}{|c|c|c|c|c|c|c|c|c|c|}
\hline Region & $\begin{array}{c}\text { Financ- } \\
\text { ing }\end{array}$ & $\begin{array}{l}\text { Govern- } \\
\text { ment } \\
\text { policy }\end{array}$ & $\begin{array}{c}\text { Education } \\
\text { system }\end{array}$ & R\&D & $\begin{array}{c}\text { Commercial and } \\
\text { professional } \\
\text { infrastructure }\end{array}$ & $\begin{array}{c}\text { Market } \\
\text { open- } \\
\text { ness }\end{array}$ & $\begin{array}{c}\text { Physical } \\
\text { infra- } \\
\text { structure }\end{array}$ & $\begin{array}{c}\text { Entre- } \\
\text { preneurial } \\
\text { activity }\end{array}$ & CLASS \\
\hline \multicolumn{9}{|c|}{ Poland } & \\
\hline Małopolskie & 0.11 & 0.57 & 0.51 & 0.04 & 0.32 & 0.55 & 0.28 & 0.70 & $D$ \\
\hline Śląskie & 0.13 & 0.64 & 0.49 & 0.01 & 0.39 & 0.62 & 0.30 & 0.74 & $D$ \\
\hline Wielkopolskie & 0.10 & 0.58 & 0.51 & 0.03 & 0.45 & 0.60 & 0.69 & 0.76 & $C$ \\
\hline Zachodniopomorskie & 0.14 & 0.88 & 0.38 & 0.07 & 0.13 & 0.54 & 0.10 & 1.00 & $E$ \\
\hline Lubuskie & 0.06 & 0.92 & 0.35 & 0.19 & 0.52 & 0.55 & 0.00 & 0.70 & $E$ \\
\hline Dolnośląskie & 0.14 & 1.00 & 0.42 & 0.04 & 0.42 & 0.59 & 0.69 & 0.85 & $D$ \\
\hline Opolskie & 0.12 & 0.84 & 0.33 & 0.22 & 0.32 & 0.56 & 0.41 & 0.79 & $E$ \\
\hline Kujawsko-Pomorskie & 0.06 & 0.79 & 0.35 & 0.08 & 0.39 & 0.55 & 0.00 & 0.64 & $E$ \\
\hline Warmińsko-mazurskie & 0.06 & 0.87 & 0.33 & 0.17 & 0.29 & 0.51 & 0.00 & 0.61 & $F$ \\
\hline Pomorskie & 0.14 & 0.70 & 0.53 & 0.06 & 0.55 & 0.58 & 0.00 & 0.93 & $D$ \\
\hline Łódzkie & 0.11 & 0.65 & 0.52 & 0.05 & 0.45 & 0.56 & 0.08 & 0.62 & $D$ \\
\hline Świętokrzyskie & 0.03 & 0.73 & 0.44 & 0.18 & 0.00 & 0.52 & 0.00 & 0.59 & $\boldsymbol{F}$ \\
\hline Lubelskie & 0.06 & 0.54 & 0.46 & 0.11 & 0.26 & 0.49 & 0.00 & 0.48 & $E$ \\
\hline Podkarpackie & 0.00 & 0.50 & 0.41 & 0.13 & 0.23 & 0.52 & 0.00 & 0.55 & $E$ \\
\hline Podlaskie & 0.05 & 0.48 & 0.42 & 0.21 & 0.23 & 0.49 & 0.00 & 0.64 & $E$ \\
\hline Mazowieckie & 0.28 & 0.70 & 0.43 & 0.00 & 0.52 & 0.70 & 0.17 & 0.92 & $D$ \\
\hline \multicolumn{10}{|c|}{ Czech Republic } \\
\hline Prague & 0.96 & 0.00 & 1.00 & 0.15 & 1.00 & 0.63 & 0.05 & 0.97 & $A$ \\
\hline Central Bohemia & 0.65 & 0.06 & 0.81 & 0.27 & 0.61 & 0.27 & 0.80 & 0.59 & $A$ \\
\hline Southwest & 0.57 & 0.08 & 0.86 & 0.28 & 0.52 & 0.27 & 0.53 & 0.55 & $A$ \\
\hline Northwest & 0.46 & 0.36 & 0.40 & 0.36 & 0.58 & 0.09 & 0.13 & 0.43 & $D$ \\
\hline Northeast & 0.52 & 0.12 & 0.82 & 0.22 & 0.45 & 0.17 & 0.00 & 0.54 & $B$ \\
\hline Southeast & 0.52 & 0.17 & 0.76 & 0.20 & 0.55 & 0.20 & 1.00 & 0.53 & $A$ \\
\hline Central Moravia & 0.48 & 0.26 & 0.69 & 0.30 & 0.32 & 0.18 & 0.00 & 0.48 & $C$ \\
\hline Moravian-Silesian & 0.46 & 0.47 & 0.52 & 0.37 & 0.39 & 0.17 & 0.00 & 0.37 & $D$ \\
\hline \multicolumn{10}{|c|}{ Slovakia } \\
\hline Bratislava Region & 0.74 & 0.22 & 0.81 & 0.36 & 0.45 & 0.42 & 0.47 & 0.25 & $A$ \\
\hline Western Slovakia & 0.33 & 0.45 & 0.62 & 0.42 & 0.55 & 0.16 & 0.63 & 0.01 & $c$ \\
\hline Central Slovakia & 0.26 & 0.81 & 0.35 & 0.65 & 0.32 & 0.09 & 0.22 & 0.00 & $\boldsymbol{F}$ \\
\hline Eastern Slovakia & 0.22 & 0.93 & 0.26 & 0.60 & 0.39 & 0.08 & 0.17 & 0.00 & $\boldsymbol{F}$ \\
\hline \multicolumn{10}{|c|}{ Hungary } \\
\hline Budapest & 1.00 & 0.11 & 0.44 & 0.16 & 0.94 & 0.51 & 0.89 & 0.44 & $A$ \\
\hline Central Transdanubia & 0.46 & 0.06 & 0.56 & 0.71 & 0.74 & 0.24 & 0.78 & 0.28 & B \\
\hline Western Transdanubia & 0.52 & 0.02 & 0.67 & 0.74 & 0.81 & 0.14 & 0.50 & 0.30 & $A$ \\
\hline $\begin{array}{l}\text { Southern } \\
\text { Transdanubia }\end{array}$ & 0.35 & 0.13 & 0.38 & 0.85 & 0.61 & 0.12 & 0.12 & 0.26 & D \\
\hline Northern Hungary & 0.46 & 0.24 & 0.30 & 0.83 & 0.55 & 0.15 & 0.81 & 0.20 & $D$ \\
\hline Northern Great Plain & 0.24 & 0.12 & 0.32 & 0.62 & 0.45 & 0.12 & 0.10 & 0.22 & $D$ \\
\hline Southern Great Plain & 0.31 & 0.10 & 0.44 & 0.63 & 0.55 & 0.20 & 0.32 & 0.25 & $c$ \\
\hline \multicolumn{9}{|c|}{ Visegrad Group countries } & \\
\hline Average & 0.32 & 0.46 & 0.51 & 0.29 & 0.46 & 0.38 & 0.29 & 0.52 & \\
\hline
\end{tabular}

Source: Own elaboration based on Eurostat, www.bdl.stat.gov.pl, www.czso.cz, www.slovak.statistics. sk and www.ksh.hu 
Table A2: The average values of variables for the entrepreneurship indicator in the GEM areas in 2018, and the classification of regions

\begin{tabular}{|c|c|c|c|c|c|c|c|c|c|}
\hline Region & $\begin{array}{c}\text { Financ- } \\
\text { ing }\end{array}$ & $\begin{array}{l}\text { Govern- } \\
\text { ment } \\
\text { policy }\end{array}$ & $\begin{array}{c}\text { Education } \\
\text { system }\end{array}$ & R\&D & $\begin{array}{c}\text { Commercial and } \\
\text { professional } \\
\text { infrastructure }\end{array}$ & $\begin{array}{c}\text { Market } \\
\text { openness }\end{array}$ & $\begin{array}{c}\begin{array}{c}\text { Physical } \\
\text { infra- } \\
\text { structure }\end{array} \\
\end{array}$ & $\begin{array}{c}\text { Entre- } \\
\text { preneurial } \\
\text { activity }\end{array}$ & CLASS \\
\hline \multicolumn{10}{|c|}{ Poland } \\
\hline Małopolskie & 0.14 & 0.18 & 0.73 & 0.04 & 0.19 & 0.53 & 0.43 & 0.64 & c \\
\hline Śląskie & 0.29 & 0.24 & 0.72 & 0.02 & 0.23 & 0.57 & 0.50 & 0.58 & c \\
\hline Wielkopolskie & 0.22 & 0.10 & 0.69 & 0.03 & 0.27 & 0.58 & 0.60 & 0.63 & c \\
\hline Zachodniopomorskie & 0.08 & 0.28 & 0.48 & 0.09 & 0.08 & 0.51 & 0.07 & 0.76 & $E$ \\
\hline Lubuskie & 0.22 & 0.19 & 0.46 & 0.21 & 0.31 & 0.53 & 0.26 & 0.63 & $E$ \\
\hline Dolnośląskie & 0.10 & 0.23 & 0.62 & 0.04 & 0.25 & 0.59 & 0.63 & 0.73 & c \\
\hline Opolskie & 0.10 & 0.19 & 0.71 & 0.24 & 0.19 & 0.52 & 0.25 & 0.58 & $D$ \\
\hline Kujawsko-Pomorskie & 0.07 & 0.34 & 0.43 & 0.11 & 0.23 & 0.52 & 0.47 & 0.50 & $E$ \\
\hline Warmińsko-Mazurskie & 0.15 & 0.49 & 0.19 & 0.18 & 0.17 & 0.49 & 0.00 & 0.50 & $F$ \\
\hline Pomorskie & 0.19 & 0.19 & 0.50 & 0.06 & 0.33 & 0.55 & 0.19 & 0.71 & $D$ \\
\hline Łódzkie & 0.07 & 0.35 & 0.59 & 0.08 & 0.27 & 0.54 & 0.64 & 0.49 & D \\
\hline Świętokrzyskie & 0.07 & 0.51 & 0.36 & 0.21 & 0.00 & 0.49 & 0.00 & 0.50 & $\boldsymbol{F}$ \\
\hline Lubelskie & 0.00 & 0.57 & 0.49 & 0.12 & 0.16 & 0.47 & 0.00 & 0.44 & $\boldsymbol{F}$ \\
\hline Podkarpackie & 0.04 & 0.59 & 0.40 & 0.12 & 0.14 & 0.51 & 0.44 & 0.45 & $\boldsymbol{F}$ \\
\hline Podlaskie & 0.08 & 0.22 & 0.60 & 0.24 & 0.14 & 0.48 & 0.00 & 0.47 & $E$ \\
\hline Mazowieckie & 0.12 & 0.50 & 0.45 & 0.00 & 0.31 & 0.50 & 0.30 & 0.79 & $E$ \\
\hline \multicolumn{10}{|c|}{ Czech Republic } \\
\hline Prague & 0.77 & 0.00 & 0.89 & 0.09 & 0.85 & 0.57 & 0.13 & 1.00 & $A$ \\
\hline Central Bohemia & 0.52 & 0.08 & 0.90 & 0.20 & 0.61 & 0.28 & 1.00 & 0.47 & $A$ \\
\hline Southwest & 0.37 & 0.02 & 0.89 & 0.24 & 0.56 & 0.17 & 0.47 & 0.44 & $A$ \\
\hline Northwest & 0.27 & 0.24 & 0.27 & 0.35 & 0.51 & 0.08 & 0.36 & 0.32 & $D$ \\
\hline Northeast & 0.36 & 0.08 & 0.80 & 0.19 & 0.37 & 0.18 & 0.11 & 0.43 & B \\
\hline Southeast & 0.38 & 0.11 & 0.81 & 0.15 & 0.42 & 0.16 & 0.72 & 0.34 & $A$ \\
\hline Central Moravia & 0.30 & 0.10 & 0.92 & 0.26 & 0.37 & 0.17 & 0.46 & 0.40 & $A$ \\
\hline Moravian-Silesian & 0.29 & 0.27 & 0.64 & 0.30 & 0.42 & 0.14 & 0.28 & 0.35 & c \\
\hline \multicolumn{10}{|c|}{ Slovakia } \\
\hline Bratislava Region & 1.00 & 0.18 & 0.65 & 0.16 & 0.56 & 0.49 & 0.31 & 0.38 & $\boldsymbol{A}$ \\
\hline Western Slovakia & 0.36 & 0.34 & 0.71 & 0.21 & 0.51 & 0.11 & 0.44 & 0.03 & $B$ \\
\hline Central Slovakia & 0.37 & 0.70 & 0.53 & 0.31 & 0.37 & 0.10 & 0.29 & 0.02 & $D$ \\
\hline Eastern Slovakia & 0.26 & 1.00 & 0.25 & 0.31 & 0.42 & 0.15 & 0.33 & 0.00 & $\boldsymbol{F}$ \\
\hline \multicolumn{10}{|c|}{ Hungary } \\
\hline Budapest & 0.15 & 0.20 & 0.77 & 0.16 & 1.00 & 0.35 & 0.86 & 0.30 & $A$ \\
\hline Central Transdanubia & 0.18 & 0.10 & 0.39 & 0.79 & 1.00 & 0.14 & 0.74 & 0.17 & B \\
\hline Western Transdanubia & 0.15 & 0.08 & 0.62 & 0.79 & 0.95 & 0.12 & 0.54 & 0.18 & $B$ \\
\hline Southern Transdanubia & 0.10 & 0.49 & 0.13 & 0.99 & 0.95 & 0.01 & 0.87 & 0.16 & $D$ \\
\hline Northern Hungary & 0.04 & 0.39 & 0.11 & 1.00 & 1.00 & 0.05 & 0.50 & 0.10 & $E$ \\
\hline Northern Great Plain & 0.05 & 0.60 & 0.11 & 0.68 & 1.00 & 0.01 & 0.56 & 0.12 & $E$ \\
\hline Southern Great Plain & 0.11 & 0.23 & 0.45 & 0.70 & 1.00 & 0.04 & 0.59 & 0.16 & $c$ \\
\hline \multicolumn{9}{|c|}{ Visegrad Group countries } & \\
\hline Average & 0.23 & 0.30 & 0.55 & 0.28 & 0.46 & 0.33 & 0.41 & 0.42 & \\
\hline
\end{tabular}

Source: Own elaboration based on Eurostat, www.bdl.stat.gov.pl, www.czso.cz, www.slovak.statistics.sk, and www.ksh.hu 


\section{References}

Anton, S. G., Onofrei, M. (2016). Public Policies to Support Entrepreneurship and SMEs. Empirical Evidences from Romania. Transylvanian Review of Administrative Sciences, 12(47E), 5-19.

Autio, E., Pathak, S., Wennberg, K. (2013). Consequences of Cultural Practices for Entrepreneurial Behaviors. Journal of International Business Studies, Forthcoming, 44(4), 334-362, https://doi.org/10.1057/jibs.2013.15

Bampoky, C., Blanco, L., Liu, A., et al. (2013). Economic Growth and the Optimal Level of Entrepreneurship. Pepperdine University Pepperdine Digital Commons, School of Public Policy. Working Papers No. 6-1-2013. Available at: https://digitalcommons. pepperdine.edu/sppworkingpapers/46/

Beck, T., Demirgüç-Kunt, A., Maksimovic, V. (2005). Financial and Legal Constraints to Growth: Does the Firm Size Matter? The Journal of Finance, 60(1), 137-177, https://doi.org/10.111 1/j.1540-6261.2005.00727.xBeck, T., Demirgüç-Kunt, A., Maksimovic, V. (2008). Financial Patterns Around the World: Are Small Firms Different? Journal of Financial Economics, 89(3), 467-487, https://doi.org/10.1016/j.jfineco.2007.10.005

Bjørnskov, C., Foss, N. J. (2006). Economic Freedom and Entrepreneurial Activity: Some CrossCountry Evidence. Center for Strategic Management and Globalization, SMG. Working Papers No. 15/2006, https://doi.org/10.2139/ssrn.982128

Cerić, D. (2015). Macro-regional Empirical Analysis of the Economic Climate in Visegrad Countries. Studia Obszarów Wiejskich, 39, 49-58, https://doi.org/10.7163/sow.39.4

Curran, D., Lynn, T., O'Gorman, C. (2016). The Role of Personal Factors in the Location Decision of Software Services Start-up Firms. European Planning Studies, 24(3), 551-567, https://doi.org/10.1080/09654313.2015.1046369

Díaz-Casero, J. C., de la Cruz Sánchez-Escobedo, M., Díaz-Aunión, D. A. M., et al. (2012). Economic Freedom and Entrepreneurial Activity. Management Decision, 50(9), 1686-1711, https://doi.org/10.1108/00251741211266750

Dvouletý, O. (2017). What is the Relationship between Entrepreneurship and Unemployment in Visegrad Countries? Central European Business Review, 6(2), 42-53, https://doi.org/10.18267/j.cebr.179

Fossen, F., Büttner, T. (2013). The Returns to Education for Opportunity Entrepreneurs, Necessity Entrepreneurs, and Paid Employees. Economics of Education Review, 37(1), 66-84. Available at: https://www.learntechlib.org/p/206719

Global Entrepreneurship Monitor (2011). Key Indicators and Definitions. Available at: http://www.gemconsortium.org/docs/download/414

Godlewska-Majkowska, H. (2008). Atrakcyjność inwestycyjna polskich regionów. W poszukiwaniu nowych miar [Investment attractiveness of Polish regions. In search of new measures.]. Studia i Analizy Instytutu Przedsiębiorstwa, tom „Innowacyjność jako czynnik wzrostu atrakcyjności inwestycyjnej polskich regionów w latach 2002-2007", Oficyna Wydawnicza SGH, Warszawa, pp. 55-234. 
Holienka, M. (2015). Entrepreneurial Environment in Slovakia: Multi-Perspective Comparison with Innovation-Driven Economies. Procedia Economics and Finance, 34, 437-444, https://doi.org/10.1016/s2212-5671(15)01652-4Entrepreneurial Environment and Economic Growth: What Affects the Productiveness of Business Activity at Macro Level? in Dudycz, T., Osbert-Pociecha, G., Brycz, B., eds., The Essence and Measurement of Organizational Efficiency. Switzerland: Springer International Publishing, pp. 79-95, https://doi.org/10.1007/978-3-319-21139-8_6

Holienka, M., Gál, P., Kovačičová, Z. (2017). Drivers of Student Entrepreneurship in Visegrad Four Countries: Guesss Evidence. Central European Business Review, 6(2), 54-63, https://doi.org/10.18267/j.cebr.180

Korosteleva, J., Mickiewicz, T. (2011). Start-up Financing in the Age of Globalisation. UCL SSEES Centre for Comparative Economics. Economics Working Paper No. 96, pp. 1-30. Available at: http://discovery.ucl.ac.uk/1382005/2/1382005.pdf

Levie, J., Autio, E., Acs, Z., et al. (2014). Global Entrepreneurship and Institutions: An Introduction. Small Business Economics, 42, 437-444, https://doi.org/10.1007/s11187-013-9516-6

Lukeš, M., Zouhar, J. (2016). The Causes of Early-Stage Entrepreneurial Discontinuance. Prague Economic Papers, 25(1), 19-36, https://doi.org/10.18267/j.pep.534

Oancea, B., Pospíšil, R., Drăgoescu, R. M. (2017). Higher Education and Economic Growth:

A Comparison between the Czech Republic and Romania. Prague Economic Papers, 26(4), 467-486, https://doi.org/10.18267/j.pep.622

OECD (2006). The SME Financing Gap (Vol. 1): Theory and Evidence. Paris: OECD Publishing, https://doi.org/10.1787/9789264029415-en

PARP (Polish Agency for Enterprise Development) (2018). Global Entrepreneurship Monitor Report - Poland 2017/18, pp. 22. Available at: https://www.parp.gov.pl/component/ publications/publication/global-entrepreneurship-monitor-poland-2017-en

Poschke, M. (2013). Entrepreneurs Out of Necessity. Applied Economics Letters, 20(7), 658-663, https://doi.org/10.1080/13504851.2012.727968

Roper, S., Scott, J. M. (2009). Perceived Financial Barriers and the Start-up Decision: An Econometric Analysis of Gender Differences Using GEM Data. Munich Personal RePEc Archive. MPRA Paper No. 23342. Available at: https://mpra.ub.uni-muenchen. de/23342/1/MPRA_paper_23342.pdf

Sorgner, A., Fritsch, M. (2018). Entrepreneurial Career Paths: Occupatonal Context and the Propensity to Become Self-employed. Small Business Economics, 51(1), 129-152, https://doi.org/10.1007/s11187-017-9917-z

Storey, D. (1994). Understanding the Small Business Sector. New York: Routledge, https://doi.org/10.4324/9781315544335

Stuetzer, M., Obschonka, M., Brixy, U., et al. (2014). Regional Characteristics, Opportunity Perception and Entrepreneurial Activities. Small Business Economics, 42(2), 221-244, https://doi.org/10.1007/s11187-013-9488-6 
Szerb, L., Komlósi, E., Ács, Z. J., et al. (2013). Measuring Regional Entrepreneurship in Hungary. Proceedings- 11 th International Conference on Mangement, Enterprise and Benchmarking (MEB 2013), Óbuda University, Keleti Faculty of Business and Management, pp. 49-64. Available at: http://kgk.uni-obuda.hu/sites/default/files/04_Szerb_et_al.pdf

Šúbertová, E. (2009). Analysis of Entrepreneurial Environment in the Slovak Republic - Results of a Research Conducted on a Selected Group of Small and Mediumsized Enterprises. Available at: https://pdfs.semanticscholar.org/309f/ a0d2887d04c512e830f745ba0ba2f76535f2.pdf

Turro, A., Urbano, D., Peris-Ortiz, M. (2014). Culture and Innovation: The Moderating Effect of Cultural Values on Corporate Entrepreneurship. Technological Forecasting and Social Change, 88, 360-369, https://doi.org/10.1016/j.techfore.2013.10.004

Zarębski, P. (2012). Atrakcyjność inwestycyjna obszarów wiejskich w Polsce [Investment Attractiveness of Rural Areas in Poland]. Zeszyty Naukowe SGGW w Warszawie - Problemy Rolnictwa Światowego, 12(27), 169-178. Available at: http://www.wne.sggw.pl/ czasopisma/pdf/PRS_2012_T12\%2827\%29_z4.pdf

www.bdl.stat.gov.pl

www.doingbusiness.org

wWw.czso.cz

www.ec.europa.eu

www.gemconsortium.org

www.ksh.hu

www.slovak.statistics.sk 